\title{
Secondary contamination in Polish drinking water
}

\author{
J. Chudzicki ${ }^{1}$, M. Kwietniewski ${ }^{1}$, M. Iwanek ${ }^{2} \&$ P. Suchorab ${ }^{2}$ \\ ${ }^{I}$ Faculty of Environmental Engineering, \\ Warsaw University of Technology, Poland \\ ${ }^{2}$ Faculty of Environmental Engineering, \\ Lublin University of Technology, Poland
}

\begin{abstract}
One of main problems that exploiting water supply network companies have to deal with is a secondary contamination of water transported by a distribution system. That problem has escalated after the political system transformation in 1989, which turned out to be typical for Central and East Europe countries. In this paper, selected causes and the scale of this phenomenon is shown. Attention was paid to the evolutionary changes which have occurred in water supply networks through last 20 years. At first, oversizing of water supplied networks was assumed as the main reason of the recontamination, as a result of an essential decrease of industrial and individual customer's water demand. Gradually, other factors were noticed, such as a dynamic increase of exploited water supply pipe's length and material's influence. As additional factors, the authors also acknowledge results of actions taken in order to raise water supply enterprises efficiency - especially with connecting small, local networks into group systems.

Presented considerations and analysis were based on an available domestic literature and survey research undertaken in Polish water supply companies in the years 2010-2012. The authors also present exemplary results of their own research, realized in selected water supply systems of different sizes. This research illustrate an influence of the pipes' material (PVC and PE), but also the unwelcome effects of connecting local water supply networks into one group system.
\end{abstract}

Keywords: water supply, water quality, quality deterioration. 


\section{Introduction}

The problem of a secondary contamination is present in water supply systems all over the world [1-3]. Causes of this phenomenon have different basis, appear individually as well as coexist and overlap, worsening the quality of distributed water. Factors that influence the water contamination can be divided into several groups: connected with water (ignored in the presented paper), network's hydraulic, period and quantity of exploitation, material and sealing of pipes as well as connected with the network's structure [4-9]. Mentioned factors do not always individually affects the quality of water distributed by water supply network, but often one factor implicates changes of quality in many others impact areas [10].

In Poland, the problem of a distributed water recontamination escalated after the political transformation in 1989-1990, what turned out to be typical for Central and East Europe countries [11, 12]. Introducing a market-economy and obtaining an access to new technologies causes wide-ranging changes in functioning and building of new water supply networks. The awareness of water consumers has also increased. These factors caused, that the problem of water quality delivered to customers was systematically taking a key place in water supply enterprise's activities.

The purpose of this paper is to present an issue of the recontamination of water in polish water supply systems. The presented paper was mainly based on analysis of available materials in Poland released by enterprises as well as scientists dealing with the problem of water recontamination. Additionally, our own research, taken in selected water supply companies, was used as an example.

\section{Structure of water supply networks in Poland}

The structure of water supply enterprises in Poland remained unchanged for almost 50 years. Companies of municipal character, that respond to water delivery to singular towns or rural settlement, dominate the water supply segment. Despite the fact that recently some tendencies of grouping systems and enterprises into bigger units have occurred, they cannot be considered as corporations with even regional range.

Since 1990, a dynamic increase of exploited water supply networks can be observed in Poland. During the last 21 years, that length has magnified almost 3 times (Figure 1).

The result of this intensive water supply development is a significant growth of Polish inhabitants using collective water supply systems, which currently averagely amounts to $87.2 \%$ (95.2\% in cities, $74.7 \%$ in rural settlements).

Also the structure of water supply material has changed (Figure 2).

Currently, water networks in Poland are mainly built of traditional materials, such us cast iron and steel, which in all compose almost $50 \%$ of the total length. Systematically, the share of plastic materials is increasing. 


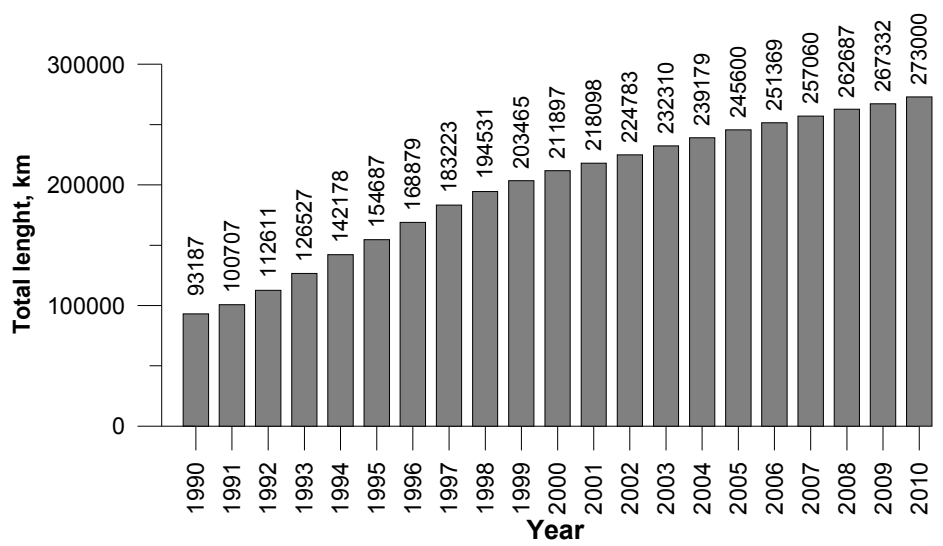

Figure 1: $\quad$ Length of Polish water supply networks 1990-2010 [13].

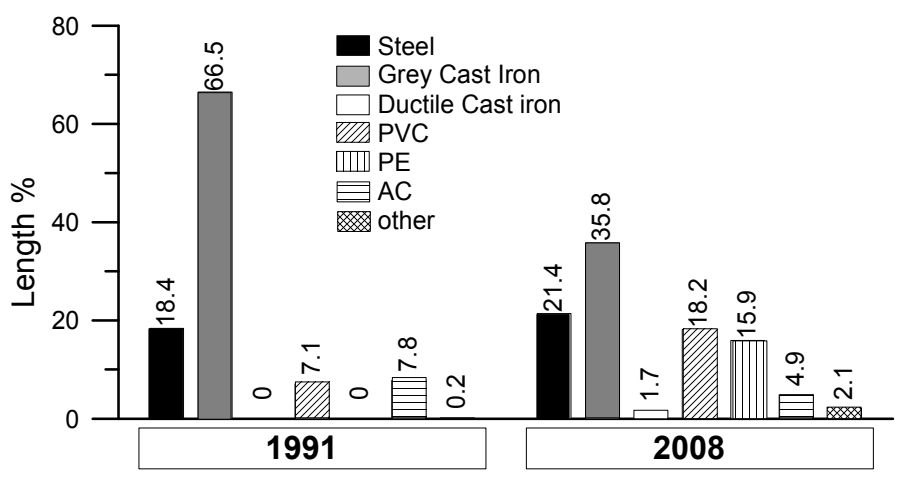

Figure 2: Material structure of the analysed water supply networks in Poland in 1991 and 2008 [13].

Pipes functioning for over 50 years comprised almost $50 \%$ in 2004 , and in major part of analyzed cities 25-50 years old water network embraces $30-45 \%$ of the water supply network length $[14,15]$. Above data suggest, that a technical state of water pipe is not in good condition, what is confirmed by average failure intensity indicator, amounted in Poland to 0.36 damage per kilometre per year [13].

From the point of view of secondary contamination, an important factor that determinates the work of the water supply systems is water demand with reference to 1 consumer. That demand is systematically decreasing since 1993 (Figure 3).

In Figure 3, standards of water demand used in a process of designing water supply systems are also presented. A comparison of these standards with a real water demand points, that even at the stage of designing, water supplied systems were oversized. That led to a significant degradation of hydraulic conditions. 


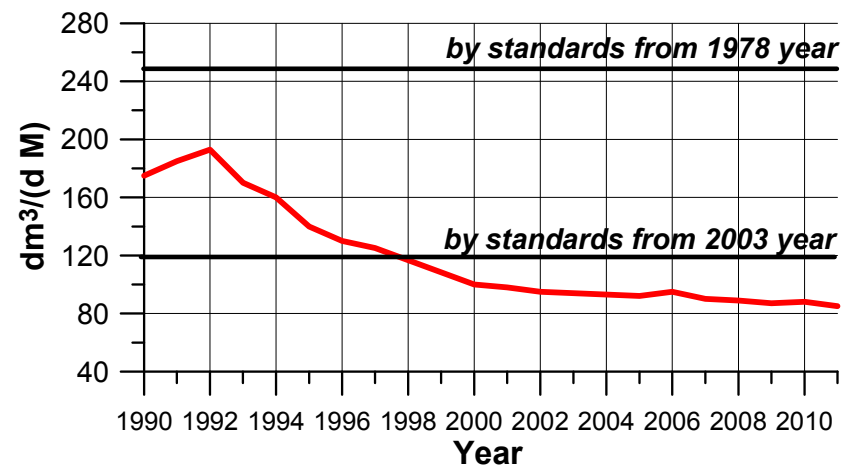

Figure 3: $\quad$ Water demand in the years 1990-2010 [16].

Oversizing of water supply systems in Poland relates not only to the distribution networks, but also to the other elements, including water pump stations. A significant variability of water pressure in water distribution systems has occurred, with the possibility of crossing the maximum pressure. It effects by loses in water supply systems. A rising quantity of water pressure into networks, despite the continuous decrease of its demand, started generating of more and more water supply exploitation costs what disturbs water supply enterprises. It led to a situation, where it was necessary to take actions in order to prevent water losses [17], which in Poland are estimated averagely at the level of approx. 19\%.

Implementing the rules of market-economy in Poland led to an escalation of a process of combining local water supply systems into bigger groups. It is especially visible in rural areas; however this process applies also to cities [12, 17]. This action increases effectiveness of enterprises, unfortunately also results by rising of water age in water distribution systems, with all related consequences.

Currently in Poland, ensuring water in quantity demanded by customers is not a problematic issue. However, problems with maintaining water quality required by law and stabilization of pressure in networks has emphasized. That is why there is a rising need of an effective monitoring and undertakings of actions to counteract the recontamination phenomenon and pressure stabilization in distribution networks.

\section{Secondary contamination in Polish water networks}

Research undertaken in Poland confirms the crossing of many pollutant indicators in water transported by water supply networks as a result of secondary contamination. In order to illustrate this phenomenon in the country-scale, results of research undertaken in 2006 in urban water supply networks is shown [18] (Figure 4). By measures carried on-line and laboratory analysis, quality parameters of water from 132 Polish urban water supply networks were studied. Examined networks supplied water for 15 million inhabitants, what is $46.4 \%$ of 
all inhabitants supplied by collective water supply systems. In all cases, water pumped into networks fulfilled quality requirements given by Polish standards. Carried research revealed that in every analyzed system there was a crossing of permissible value content of one or few rated water contamination indicators. In $78.0 \%$ of examined water supply networks most often crossed parameters were: iron, manganese and turbidity, colour, bacteria amount in $22^{\circ} \mathrm{C}$ and free chlorine. The other crossed parameters, but more rarely, were: ammonia, nitrates and nitrites, Coli bacteria, chloramines, fluorides, streptococcus, $\mathrm{pH}$, water hardness and odour.

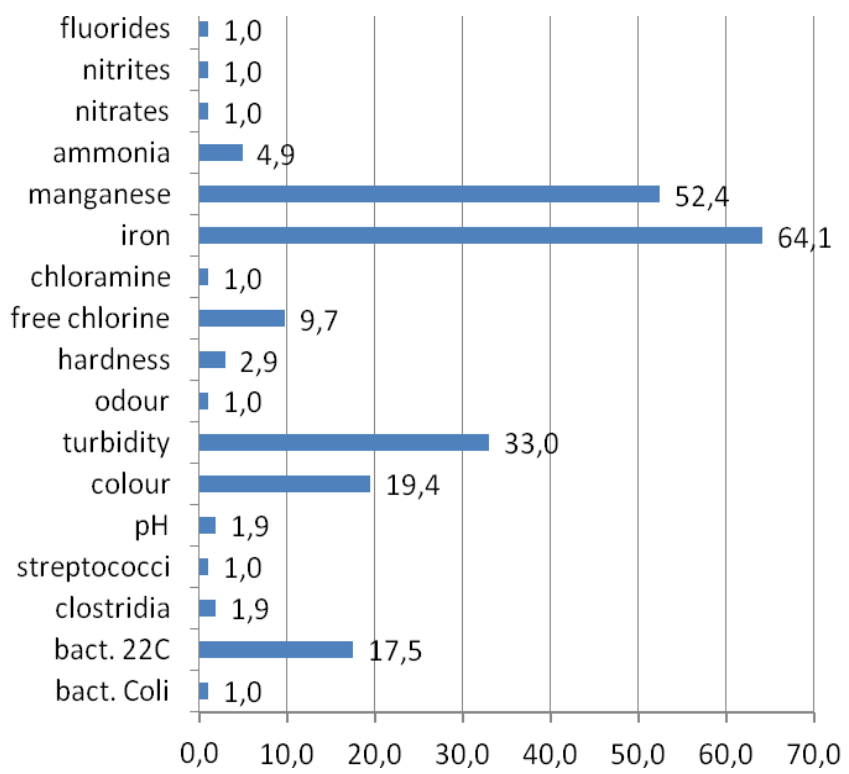

Figure 4: Percentage share of systems, in which permissible content values of selected quality parameters of water taken from distribution system were crossed [18].

\subsection{Hydraulic conditions}

The influence of hydraulic work conditions of water supply network on decreasing quality of transferred water is illustrated in Tab. 1. In the table, there are presented results of research of physical-chemical composition of water from water supply network of one of Polish cities, where the velocity of water in main water pipe was $0.1-0.2 \mathrm{~m} / \mathrm{s}$, and at night was smaller than $0.1 \mathrm{~m} / \mathrm{s}$, while a velocity in distribution pipes was $0.15-0.25 \mathrm{~m} / \mathrm{s}$. The studied water supply network is an example of a typical water network in Poland.

In Table 1 it can be noticed, that the amount of free chlorine was typically decreasing together with growing away the measurement point from a water purification station. However, value of water colour, turbidity, Total Organic 


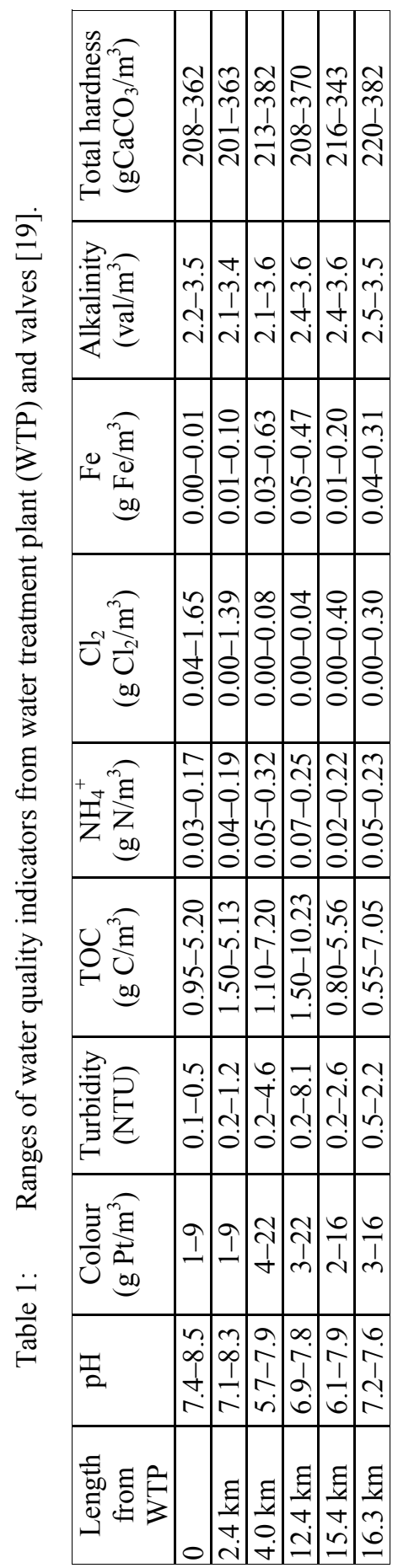


Carbon, total iron and total hardness was increasing with growing away from WTP. Water $\mathrm{pH}$ has minimally decreased, a value of ammonia meaninglessly raised and total alkalinity didn't change.

\subsection{Network's age}

A growing old network breakdowns more often, what intensifies the leakiness phenomenon what next results in secondary contamination threat of transported water. Basing on data relating to the water supply network's exploitation time of 174 cities in Poland, it was stated that:

$-50 \%$ of water supply network's length was over 50 years old;

$-30-45 \%$ of water supply network's length was $25-50$ years old.

The older the network, especially exploited in unfavourable hydraulic conditions, the bigger the value of massed sediment inside the pipes. It is conducive for biofilm growth. It is also relatively easy to wash away sediments, e.g. in conditions of increased water consumption, what periodically results in quality degradation at consumer's points [19, 20].

\subsection{Network breakdowns}

The recontamination of transferred water may be also a consequence of network pipe's breakdowns. Research undertaken in 2000-2003 [20] revealed, that a water stagnation caused by deceptive stop of its flow and a next restart of exploitation of these pipes, resulted in water recontamination in many tests fragments, up to the abnormal level. The biggest changes were observed in reference to water colour (six-time growth of this indicator was marked), turbidity (growth from 4 NTU to 45 NTU), iron, ammonia and total organic carbon.

\subsection{Factors related to a material and a sealing of a pipe}

Changes of the water quality in its distribution systems may be also a result of interaction between water and a material, with which water contacts. There is a commonly known fact, that without protective cover, metal pipes are in danger of corrosion. The effect of that is a significant growth of iron in transferred water. In Poland, one of the most used methods of protecting cost-iron pipes is a cement lining. Authors of this paper attempted to define a influence of this cement lining on the transferred water quality [21]. The growth of boron (19\%), sodium ( $9 \%$ ) gallium (12\%) and barium (4\%) was affirmed.

Research undertaken in conditions of PVC networks revealed the growth of lead content in transferred water (up to $0.05 \mathrm{mgPb} / \mathrm{dm}^{3}$ ) [22]. In a case of water from PE pipes, 19 organic compounds such as xylene, styrene, phenols and ethylmethylbenzene as well as BHT [23] were identified.

In the ground there may be different substances. Soil is in danger of contamination of chemicals. An example of this may be petroleum-derived substances, which can penetrate through walls of PE pipes. In Poland there are no law regulations that prevent using those pipes in contaminated ground. 
Research undertaken in the years 2010-2012 [24] revealed the presence of MTBE - methyl tert-butyl ether (23.2 ppb) in water taken from transfer pipeline placed in chemically contaminated ground. These substances were not present in the water which entered into water supply pipes.

A fundamental impact on water secondary contamination have anticorrosive tar and asphalt coatings, present in a major part of water pipes in Poland. Research of 72 tar and asphalt coatings resulted that all tar coatings (25) were evaluated negatively. Only 2 out of 47 asphalt coatings were rated positively. The reason of the negative evaluation of these anticorrosive coatings was an excessive penetration of PAHs into the water as well as very strong influence on the organoleptic water characteristics and intensive penetration of organic compounds into the water, what caused the an increase of COD. Out of some products also significant amounts of phenols penetrated into water. Because of that, asphalt coatings as interior anticorrosive protection were withdrawn.

\subsection{Factors related to the network's structure}

In Poland, similarly to other countries, looped water supply networks are preferred. These structures guarantee higher water delivery reliability that branched structures. Applying of looped structures extends time of water delivery to customers, however a possible increase of water delivery reliability appeals for its use. Still, it should be mentioned that supplying customers with water transferred through a different path is related with a change of water flow direction in pipes. If there are sediments in pipes, it should be taken into consideration, that these sediments will be wash away and transferred by changing direction water flow to smaller diameter pipes, where sediments can accumulate. The risk of that phenomenon is large is oversized water supply networks, where sediments can easier deposit due to smaller flow rate [26, 27].

It seemed that risk of water flow changes does not occur in branched networks. However, research undertaken by paper's authors revealed that this phenomenon is present but its intensiveness is much smaller than in case of looped structures [28].

There are also specific fragments of water supply networks such us ending segments and inactive water connections (after liquidation of water consumers, e.g. industrial plants), where, due to the very small velocities or even lack of flow, may occurs a water stagnation, sediments accumulation, possibility of sediments rotting, growth of iron and manganese bacteria or even freezing of water during winter what leads to pipe's breakdowns. Regardless of mentioned reasons, in oversized ending segments of network, a loss of disinfectant may occur. It was shown in field research [29], where in tested ending segments of network, the biggest amounts of iron was detected, with simultaneous 5-time decrease of disinfectant's concentration.

\subsection{Connecting of local systems into groups}

Implementing rules of market-economy into practice of water supply enterprise's functioning in Poland forced a cost's rationalization of their existence. It is 
mainly realized by connecting of local water systems into group systems. It is especially visible in rural conditions (currently approx. 20\%), but also relates to cities. An example of those actions in a big city scale is Górnośląski Water Supply Cluster.

Grouping of water supply systems visibly raise effectiveness of their functioning. Smaller and better qualified staff, more advance methods of water purification, better monitoring. However, in a condition of rural settlements, a problem of increased water age appears. A problematic issue is also a monitoring of widespread distribution water networks supplying water to territorially scattered consumers. It effects, more often than before political system transformation, in cases of appearance of necessary work system breaks, for time longer than 3 days, resulting on bacterial contamination of transferred water. In one of 17 Polish regions in last 2 years, the amount of that cases crossed 50.

\subsection{Lack of pressure stability}

In cases of sudden pressure changes with simultaneous water motion, it may inquire into sediment and biofilm washing away, and next to their component's penetration into network's water. During biofilm washing away it may happen to contamination of water by microorganisms. Sudden pressure decreases may also cause a water reverse flow of the interior installations, which may result in network's water recontamination by components contaminating water installation. Out of 59 water supply enterprises that authors of this paper have tested in survey research [30], over 50\% signalized problems with lack of pressure stability and problems connected with sediments and biofilm washing away.

\section{Summary}

Taking into consideration data shown in this paper, it may be claimed, that:

- an existing in Poland material and age structure of water supply networks, significant changes of water demand in last 20 years as well as organizational structure of water supply enterprises favour a recontamination phenomenon of transferred water,

- a problem of water secondary contamination in Polish water supply systems is present practically in every functioning system on Polish territory and is a major difficulty, which water supply enterprises have to deal with,

- counteracting the secondary contamination requires getting to know the mechanisms of that process. The range of contamination favouring factors taken into analysis is gradually rising.

- a contamination of water relates directly with water loses in water supply systems. Currently water loses led not only to economic loses and waste of drinking water, but also may be a great danger for public health. An every leak is a potential place of contamination's penetration, e.g. in case of a pressure loss in a network. A leak also leads to a breakdown in services, what in consequence may also lead to services complaints from customers. 


\section{Acknowledgements}

The scientific work was financed from the measures of the National Center of Research and Development as research project No. PBS1/B9/15/2012.

\section{References}

[1] Elala D., Labhasetwar P. \& Tyrrel S.F., Deterioration in water quality from supply chain to household and appropriate storage in the context of intermittent water supplies. Water Science \& Technology: Water Supply, 11.4, 2011.

[2] Mounce S., Machell J. \& Boxall J., Water quality event detection and customer complaint clustering analysis in distribution systems. Water Science \& Technology: Water Supply, 12(5), pp. 580-587, 2012.

[3] Vreeburg J.H.G. \& Boxall J.B. Discolouration in potable water distribution systems: A review. Water Research, 41, pp. 519-529, 2007.

[4] Woolschlager J.E., Rittmann B.E. \& Piriou P., Water quality decay in distribution systems - problems, causes, and new modeling tools. Urban Water Journal, 2(2), pp. 69-79, 2005.

[5] Besner M-C., Gauthier V., Trépanier M., Leclair M. \& Prévost M., Interactive analyser for understanding water quality problems in distribution systems. Urban Water Journal, 2(2), pp. 93-105, 2005.

[6] Chen M., Ohman K., Sinclair J., Petkau D., Yau R., Deng J.F., Tran T., Huston C. \& Elford T., Disinfection by-products in drinking water - a case study on Calgary, Alberta, Canada. Water Quality Research Journal of Canada, 46(3), pp. 200-210.

[7] Tsvetanova Z.G. \& Hoekstra E.J., Assessment of microbial growth potential of PVC flexible tubing in contact with drinking water. Water Science \& Technology: Water Supply, 12(4), pp. 489-495.

[8] Lee J., Lohani V.K., Dietrich A.M. \& Loganathan G.V., Hydraulic transients in plumbing systems, Water Science \& Technology: Water Supply, 12(5), pp. 619-629, 2012.

[9] Simard A., Pelletier G. \& Rodriguez M., Water residence time in a distribution system and its impact on disinfectant residuals and trihalomethanes. Journal of Water Supply: Research and Technology$A Q U A, \mathbf{6 0 . 6}, 2011$.

[10] Kowal A.L. \& Świderska-Bróż M., Oczyszczanie wody. Podstawy teoretyczne $i$ technologiczne, procesy $i$ urzadzenia. Wyd. Naukowe PWN, Warszawa 2009.

[11] Chiru E., Water quality in distribution system operation. storage crossconnections. National report Romania. Water supply, 18(1), pp. 233-234, IWA Publishing 2000.

[12] Kwietniewski M., Water quality in distribution system operation. storage. cross-connections. National report Poland. Water Supply, 18(1), pp. 229 231, 2000. 
[13] Kowalski D. \& Miszta-Kruk K., Failure of water supply networks in selected Polish towns based on the field reliability tests. Engineering Failure Analysis, 35, pp. 736-742, 2013.

[14] Kwietniewski M., Tłoczek M. \& Wysocki L., Rules for selection of material and structural solutions for the construction of water pipes. Work prepared for the order of the Capital City Warsaw Waterworks and Sewage Enterprise Ltd. under the auspices of the Economic Chamber Polish Waterworks in Bydgoszcz, 2011.

[15] Dohnalik P. \& Jędrzejewski A., Efektywna eksploatacja wodociagów. Wyd. LEMtech Konsulting sp. z o.o. Kraków Rocznik Statystyczny, GUS, 1990-2012, 2004.

[16] Polisch Statistical Yearbooks 1990-2012. http://www.stat.gov.pl/gus/index_ENG_HTML.htm

[17] Hotloś H., Analiza strat wody w systemach wodociągowych, Ochrona Środowiska, 1, pp. 17-24, 2003.

[18] Kwietniewski M. \& Sudol M., Verification of measuring point locations in water quality monitoring used in a selected water distribution system, Proc. SPIE 6159, Photonics Applications in Astronomy, Communications, Industry, and High-Energy Physics Experiments IV, 61593C, April 26, 2006.

[19] Świderska-Bróż M. \& Wolska M., Ocena wtórnego zanieczyszczenia niestabilnej chemicznie wody w systemie dystrybucji, Ochrona Środowiska, 2005.

[20] Świderska-Bróż M. \& Wolska M., Korozyjność wody wodociągowej a zjawiska zachodzące w systemie jej dystrybucji, Gaz, Woda i Technika Sanitarna, 1/2003, pp. 15-20, 2003.

[21] Wąsowski J., Kowalski D., Kowalska B., Kwietniewski M. \& Zawilska M., Badania zmian jakości wody $\mathrm{w}$ przewodach wodociągowych $\mathrm{z}$ wykładziną cementową. Ochrona Środowiska, vol. 34, 1/2012, pp. 53-58, 2012.

[22] Kowalski D., Water quality in a small network - problems and a proposal for their solution. Water Practice \& Technology 4:3, IWA Publishing 2009. doi:10.2166/wpt.2009.048

[23] Kowalska B., Kowalski D., Kwietniewski M. \& Musz A., Influence of Polyethylene Pipe on the Quality of Water in a Water Distribution System. Journal of Sustainable Development, 6(2), ISSN 1913-9063, E-ISSN 1913-9071, Canadian Center of Science and Education.

[24] Kowalska B., Kowalski D. \& Rożej A., Organic compounds migrating from plastic pipes in contact with the drinking water. Preliminary studies. Journal of Water Supply Research and Technology-AQUA, 60.3, pp. 137146, 2011.

[25] National institute of Hygiene http://www.pzh.gov.pl/page/index.php?id=801\&L=1

[26] Kulbik M., Komputerowa symulacja $i$ badania terenowe miejskich systemów wodociagowych, Wyd. Politechniki Gdańskiej, Gdańsk, 2004. 
[27] Kowalski D., Nowe metody opisu struktur sieci wodociagowych do rozwiazywania problemów ich projektowania $i$ eksploatacji. Monografie Komitetu Inżynierii Środowiska PAN, vol. 88.

[28] Kowalski D., Kowalska B., Kwietniewski.M. \& Musz A. Przepływy zwrotne w rozgałęzieniowych sieciach wodociągowych. Ochrona Środowiska, 4/2010, pp. 31-36, 2010.

[29] Kowalska B., Kowalski D. \& Musz. A., Analiza zmian wybranych parametrów jakościowych wody w przewymiarowanej sieci wodociągowej. Monografie Komitetu Inżynierii Środowiska PAN, vol. 33, II Kongres Inżynierii Środowiska, 2, pp. 543-552, 2005.

[30] Kwietniewski M., Miszta-Kruk K \& Sudoł M., Raport z własnych badań ankietowych przedsiębiorstw wodociagowych. Maszynopis., Politechnika Warszawska, Wydział Inżynierii Środowiska Zakład Zaopatrzenia w Wodę i Odprowadzania Ścieków, 2008. 